\title{
The Effect of Competence, Price and Quality of Service to The Satisfaction of Students
}

\author{
Moh. Saiful Bahri \\ Faculty of Economics University of Panca Marga Probolinggo \\ Email: saiful.bahri@upm.ac.id
}

https://doi.org/10.30741/wiga.v10i1.514

\section{A R T I C LE IN F O}

Date of entry:

30 January 2020

Revision Date:

28 February 2020

Date Received:

25 March 2020

\begin{abstract}
A B S T R A C T
The number of factors that can affect satisfaction, researchers try to see from the aspects of competence possessed by lecturers, educational staff, prices or costs to be borne by students and service quality. This research was conducted in the Management Study Program of the Faculty of Economics, University of Panca Marga Probolinggo with a sample of 100 management students from a total number of management students of 1000 . The purpose of this study was to determine whether there was a significant influence between competence, price and quality of service on student satisfaction. Based on the results of research analysis shows that competence, price and service quality together have a significant effect on student satisfaction, where the magnitude of $F$ is 19,060 with a sig level of 0,000 . Whereas the results of the research analysis partially showed that the coefficient $t$ of the competency variable, -0.201 , proved that competence had no partial effect on student satisfaction with a sig value of 0.841 . The coefficient $t$ of the price variable, 2.609 , proves that prices affect student satisfaction. If the price is raised and followed by an increase in service it will increase student satisfaction. So partially the price has a significant effect on student satisfaction. The coefficient of service quality $t$ arithmetic which is 5,531 with sig 0,000 means that partially the quality of service has a significant influence on student satisfaction, while the quality of service provides the greatest influence on student satisfaction.
\end{abstract}

Keywords: Competence, Price, Service Quality and Satisfaction

\section{INTRODUCTION}

The Faculty of Economics is an educational institution whose main activity is selling services in the field of education, especially undergraduate management and accounting study programs, therefore it is interesting to study and observe what factors affect the level of satisfaction that can be felt by students, because with known factors causing satisfaction and dissatisfaction are expected by management to be able to give enough attention to be able to manage well so as to increase satisfaction with students. 
Abdullah and Tantri (2017: 45) argue that, "Customer satisfaction is the result that buyers feel from company performance that meets their expectations. Customers are satisfied when their expectations are met and happy or happy when their expectations are exceeded. Satisfied customers will be loyal longer, buy more, be less price sensitive and make good comments about the company. Likewise students in a tertiary institution, will surely give an assessment of the manager's performance related to the services provided and compared to the price or costs incurred to receive services while also being compared with the expectations in his heart. Given the many factors that can affect satisfaction, researchers are interested to see from the aspects of competence, price or cost borne by students and the quality of service influence on student satisfaction in the faculty of economics, Management Study Program, Panca Marga University, Probolinggo.

Customer satisfaction is an emotional response to the evaluation of observations of consumption of a product or service, Tjiptono (2008: 89). While the definition of satisfaction according to Day in Tjiptono (2008: 128) "Customer satisfaction or dissatisfaction is the customer's response to the evaluation of discrepancies or disconfirmations between expectations before, or customer satisfaction is a full evaluation where the alternative chosen is at least the same or exceeds customer expectations, while dissatisfaction arises if the results do not meet expectations.

Feelings of satisfaction or dissatisfaction will be known after consumers or users compare between expectations and the reality of the products or services that have been used, as well as students as users of services in the field of education, especially higher education, namely the faculty of economics, management study program, University of Panca Marga Probolinggo, they hope to get services that can satisfy his feelings or services that are in line with student expectations. The indicators of customer satisfaction according to Tjiptono are a). Overall customer satisfaction. b). confirmation of hope c). repurchase interest d). customer availability to recommend.

Edison (2017: 140), Competence is the ability of individuals to carry out a job correctly and has advantages based on matters relating to knowledge, skills and attitudes. According to Scale in Sutrisno (2016: 202), Competence is defined as the behavioral dimension of expertise or excellence of a leader or staff having good skills, knowledge, and behavior. Meanwhile, according to Wibowo (2007: 110) competence is the ability to carry out or perform a job or task based on skills and knowledge and is supported by the work attitude required by the job.

According to Government Regulation of the Republic of Indonesia No. 66 of 2010 concerning amendments to Government Regulation Number 17 of 2010 concerning Management and Implementation of Education Chapter 1 Article 1 number 28, "lecturers are professional educators and scientists at tertiary institutions with the main task of transforming, developing, and disseminating knowledge technological and art knowledge through education, research and community service (Tri Dharma). Seeing the quite heavy duty of lecturers to carry out the Tri Dharma of Higher Education as well as to transform, develop and disseminate technological knowledge, then as a lecturer must have sufficient competence so that tasks, functions and roles can be carried out well and be able to provide satisfaction to students. Indicators of Competency according to Edison (2017: 147) are a). Knowledge b). Expertise (skill), c). Attitude

This indicator is a very important indicator for a company, because with good knowledge, appropriate and sufficient expertise, and supported by attitudes and behaviors that support will have a positive impact on the company's mining and progress. Vice versa if the knowledge, skills and attitudes or behaviors of the resources are not enough or not in accordance with needs, it will have a negative impact on the development of the company.

According to Tjiptono and Chandra (2012: 315), price is, "the amount of money (monetary unit) and / or other aspects (non-monetary) that contain certain utilities / utilities needed to obtain a product. One of the roles of price according to Tjiptono and Chandra (2012: 319), namely in retail sales, there is a segment of buyers who are very sensitive to price factors (making price the only 
consideration for buying products) and some are not. The majority of consumers are somewhat sensitive, to prices, but also consider other factors (such as brand image, store location, service, value (value), product features, and product quality). In addition, consumer perceptions of product quality are often influenced by prices.

The price is identical to the cost that must be paid by students or education development contributions (SPP) or building fees that must be paid by students, so that students are entitled to get educational services as applicable in a tertiary institution in this case the faculty of economics of management studies at the University of Panca Marga Probolinggo . With the price or costs to be paid by students will provide an overview of the services received, which will then be evaluated by students by comparing the costs incurred with the services that students feel, whether able to provide satisfaction or give dissatisfaction.

According to Stanton in Wijaya, Supariyani, and Widjojo (2013: 55) explains there are four measures or indicators of prices, namely a). Affordability of prices, b). Price suitability with quality, c). Price suitability with benefits. From these indicators will give an illustration that consumers or service users will always compare the ability or purchasing power, compared with the quality of goods or the quality of services and will be compared with the perceived benefits.

According to Kotler in Najib (2008: 76) "Service is any action or activity that can be offered by one party to another party, which is basically intangible and does not result in any ownership. Wyckof in Aditya (2006: 21) provides an understanding of "Service quality as the level of perfection expected and control of perfection to meet consumer desires". The essence of the above explanation is that the concept of general service quality is related to efforts to meet or even exceed the expectations demanded by customers.

Based on the description above, it can be explained that the quality of service is an effort made by an institution or company to meet the expectations of its customers or users. Quality of service emphasizes more on the aspect of customer satisfaction provided by the company or institution that provides its services. The success of a company engaged in the service sector is highly dependent on the quality of services offered to users or the people who use them. Parasuraman et al in Lupiyoadi (2014: 216) indicators of service quality are a). Tangibles, or physical evidence b). Reliability, or reliability c). Responsivenees, or responsiveness d). Assurance, or guarantees and certainty e). Empathy, or attention.

The purpose of this study was to determine the effect of competence, price and quality of service simultaneously on the satisfaction of students of the faculty of economics, management study program, Panca Marga University, Probolinggo. Knowing the influence of competence, price and service quality partially on the satisfaction of students of the faculty of economics, management study program, University of Panca Marga Probolinggo. Knowing the competence, price and quality of service variables that have a dominant influence on the satisfaction of students of the faculty of economics, management study program, Panca Marga University, Probolinggo.

\section{RESEARCH METHODS}

This type of research used in research is a quantitative method with a causal descriptive approach. The variables used in this study consisted of independent and dependent variables. Independent variables (X) consisted of Competencies (X1), Price / SPP (X2) and Service Quality (X3). The dependent variable was student satisfaction $(\mathrm{Y})$. The population in this study were all students of the faculty of economics in management study programs who are still active, totaling approximately 1000 students (data 2018.2) from all semesters. The existing population has a fairly high level of homogeneity meaning that seen from the characteristics of students having relatively the same conditions, namely from the middle to lower classes, so that the random sampling 
method is still considered to provide a fairly good representative level. From the number of samples taken in this study were $10 \%$ x 1000 students so that 100 students were obtained. Quantitative analysis is carried out using statistical formulas and tools in the form of SPSS programs. Before testing the influence of variables, a test was previously conducted on the results of data collection through a questionnaire that was filled in by respondents. The tests conducted are a). Test data validity. b). Data reliability test. c). Multiple Linear Regression Analysis. d). Hypothesis test.

\section{RESULTS AND DISCUSSION}

Based on the results of calculations with SPSS that the $r$ count of each statement item competency variable with a significance level of 5\% shows a greater coefficient than the coefficient $r$ table of 0.19 , this proves that all statement items of the competency variable are valid. The price variable or spp shows the coefficient number that is greater than the $r$ table coefficient of 0.19 , this proves that all statement items of the price variable are valid. The service quality variable is greater than the $r$ table coefficient of 0.19 , this proves that all statement items of the service quality variable are valid. Student satisfaction variable is greater than $r$ table which is equal to 0.19 , this shows that all statement items of student satisfaction variables are valid.

Tabel 1. Reliability

\begin{tabular}{ccccc}
\hline Variabel & Alpha Count & Standard Alpha & Item & Information \\
\hline$\left(\mathrm{X}_{1}\right)$ & 0,664 & 0,6 & 7 & Reliabel \\
$\left(\mathrm{X}_{2}\right)$ & 0,677 & 0,6 & 7 & Reliabel \\
$\left(\mathrm{X}_{3}\right)$ & 0,730 & 0,6 & 12 & Reliabel \\
$(\mathrm{Y})$ & 0,709 & 0,6 & 9 & Reliabel \\
\hline
\end{tabular}

Source: Data processed

Based on Table 1 shows that all independent and dependent variables have alpha coefficients calculated greater than the standard 0.60 , this proves that the instruments used are reliable.

Tabel 2. Multiple Regression Analysis

\begin{tabular}{cccccc}
\hline Model & \multicolumn{2}{c}{ Unstandardized } & Standard & T & sig \\
& B & Std Error & Beta & & \\
\hline (Constant) & 8,607 & 4,628 & - & 1,86 & 0,066 \\
X1 & $-0,032$ & 0,160 & $-0,016$ & $-0,201$ & 0,841 \\
X2 & 0,309 & 0,118 & 0,228 & 0,228 & 0,011 \\
X3 & 0,352 & 0,064 & 0,486 & 0,486 & 0,000 \\
\hline
\end{tabular}

Source: Data processed

Based on table 2 can be seen the magnitude of the coefficient B of each variable and can be drawn on the regression line $\mathrm{Y}=8.607+-0.032 \mathrm{X} 1+0.309 \mathrm{X} 2+0.352 \mathrm{X} 3$. The regression line can be interpreted that if $\mathrm{X} 1, \mathrm{X} 2$ and $\mathrm{X} 3$ are fixed or 0 , then student satisfaction will be 8,067 . Competency variable regression coefficient (X1) of -0.032 means that if the other independent variables are fixed and competence has increased by 1 unit, student satisfaction (Y) will increase by 0.032 . Negative coefficient means that there is a negative relationship between competence and student satisfaction, this can be ignored or it can be interpreted that the competencies possessed have not been implemented optimally. Price variable regression coefficient (X2) is 0.309 meaning 
that if the competency variable, variable service quality remains or does not change and the price variable increases by one unit, then student satisfaction increases to 8.916. Regression coefficient for variable service quality (X3) of 0.352 means that if the other variables namely competence, price in a fixed or unchanged condition and the quality of service provided increases by one unit, then student satisfaction will increase by 0.352 which is 8.959 .

Tabel 3. Simultaneous Test

\begin{tabular}{lccccc}
\hline \multicolumn{1}{c}{ Model } & $\begin{array}{c}\text { Sum of } \\
\text { Squares }\end{array}$ & df & $\begin{array}{c}\text { Mean } \\
\text { Square }\end{array}$ & F & Sig, \\
\hline Regression & 327,953 & 3 & 109,318 & 19,06 & 0,000 \\
Residual & 550,607 & 96 & 5,735 & & \\
$\quad$ Total & 878,58 & 99 & & & \\
\hline
\end{tabular}

Source: Data processed

Based on table 3 the calculated $F$ value is $19.060>$ from the $F$ table that is 2.70 with a sig level of 0.000 <alpha 0.05 , this proves that $\mathrm{H} 0$ is rejected and $\mathrm{H} 1$ is accepted, which means competency, price / spp and service quality simultaneously affect student satisfaction at the Faculty of Economics, Management Study Program, University of Panca Marga Probolinggo, and the hypothesis set is accepted.

Based on table 2 can be explained (1). $t$ arithmetic for the Competency variable $-0.201<\mathrm{t}$ table 1.98 proves that partially Competency (X1) does not affect student satisfaction (Y), with sig 0.841> alpha 0.05. (2). $\mathrm{t}$ arithmetic for the variable Price / SPP (X2) 2.609> t table 1.98 this proves that the variable Price (X2) affects the Student Satisfaction (Y). If the price is raised and followed by an increase in services such as infrastructure, the quality of lecturers and the quality of supporting staff will increase student satisfaction. So partially the price has a significant effect on student satisfaction. (3). t calculate Service Quality variable (X3) 5.531> t table 1.98 with sig 0.000 <alpha 0.05 , meaning that partially the quality of service has a significant effect on student satisfaction and the proposed hypothesis is proven.

Based on table 2 above and pay attention to the magnitude of $t$ arithmetic competence variables, price and quality of service shows that the quality of service variables that have the largest value of $\mathrm{t}$ arithmetic is 5.531 with the smallest level of sig compared with alpha 0.05 , this shows that the variable quality of service has the most influence on the satisfaction of students of the faculty of economics in management study program at the University of Panca Marga Probolinggo.

\section{CONCLUSION}

The conclusions of this study are a) Competence, price / Spp and service quality together have a significant effect on student satisfaction at the Faculty of Economics, Management Study Program, University of Panca Marga Probolinggo. b) Competency partially has no effect on student satisfaction, while price or spp and service quality have a significant effect on student satisfaction at the Faculty of Economics, Management Study Program, Panca Marga University, Probolinggo. c) The variable that has the most influence on student satisfaction at the Faculty of Economics, Management Study Program, Panca Marga University, Probolinggo, is service quality. Based on the results of the analysis that jointly competence, price and service quality have a significant effect on student satisfaction, this illustrates that competence, price and service quality should get serious attention from management so that it is better managed and professionally so that student satisfaction can be increased. The results of the partial analysis of competence have no effect on student satisfaction, this shows that not all lecturers and educational support staff have good 
competencies, so that it impacts on student dissatisfaction, or the competencies held by lecturers have not been utilized more optimally so that it has a positive impact on student satisfaction. This condition requires the management to focus more attention and professionally manage competencies in order to increase student satisfaction. Quality of service gives the greatest influence on the satisfaction felt by students, this also gives an overview to the faculty so that the quality of service is improved, so that it can provide satisfaction to students. Since satisfaction is the goal to be achieved in every service activity, management should really map out the factors that can influence satisfaction and dissatisfaction, so that the management of student satisfaction related to competence, price / spp and service quality can be more effective.

\section{REFERENCE}

Abdullah, T dan Francis, T. (2017). Manajemen Pemasaran Jakarta: PT. Rajagrafindo Persada.

Aditya, K. S. R. (2011). Pengaruh Citra Koperasi, Pelayanan dan Motivasi Anggota Terhadap Kepuasan Anggota Koperasi Pegawai Republik Indonesia. Universitas Negeri Semarang.

Arikunto, S. (2014). Prosedur Penelitian Suatu Pendekatan Praktik. Jakarta:Rineka Cipta.

Edison, E. (2017). Manajemen Sumber Daya Manusia. Bandung: Alfabeta.

Edy, S. (2016). Manajemen Sumber Daya Manusia, Kencana Prenada Media Group, Jakarta

Husaini, U. (2009). Metodologi Penelitiam Sosial.Jakarta : Bumi Aksara.

Hermawati. (2018). Pengaruh Kompetensi Pegawai, Kualitas Pelayanan dan Disiplin Kerja terhadap Kepuasan Pelanggan pada Kantor UPT Pendapatan Wilayah Makassar 01 Selatan, Provinsi Sulawesi Selatan. JURNAL MIRAI MANAGEMENT VOL 3 NO 12018

Lupiyoadi, R. (2016). Manajemen Pemasaran Jasa Berbasis Kompetensi. Jakarta: Salemba Empat

Melinda, N. F. A. (2014). Pengaruh Harga Dan Citra Terhadap Kepuasan Konsumen Angkringan Di Kelurahan Sendangadi, Mlati, Sleman. Jurnal Manajemen Vol 4 No 1 Juni 2014.

Murtiyanto, R. K, Fatchur, R. dan Christin, S. (2014). Pengaruh Kualitas Produk Dan Layanan Terhadap Kepuasan Dan Loyalitas Konsumen Pada Pengembang Pt Araya Bumi Megah Malang. Jurnal Aplikasi Manajemen Volume 12 Nomor 1 Maret 2014.

Nazir, M. (2014). Metode Penelitian, Jakarta: Ghalia Indonesia

Rienly, G. (1963) Motivasi, Kompetensi dan Budaya Kerja Pengaruhnya Terhadap Kepuasan Kerja Karyawan Out Sourcing Pada Hotel Sintesa PeninSula Manado. Jurnal EMBA 1963 Vol.1 No.4 Desember 2013, Hal. 1963-1973

Sugiyono. (2015). Metode Penelitian Kuantitatif Kualitatif dan $R \&$ D. Bandung: Alfabeta

Sugiarto. (2006). Metode Statistika, Gramedia Pustaka Utama, Jakarta

Tjiptono, F dan Gregorius, C. (2012). Pemasaran Strategik. Yogyakarta, ANDI.

Tjiptono, F. (2008). Strategi Pemasaran. Yogyakarta: CV. Andi Offset.

Tjiptono, F. (2011). Strategi Pemasaran. Edisi 3. Yogyakarta : ANDI

Siagian, D., dan Sugiarto. (2006). Metode Statistika, Gramedia Pustaka Utama, Jakarta

Wijaya, T. (2013). Metodologi penelitian ekonomi dan bisnis teori dan praktek , Graha Ilmu Jogyakarta

Warongan, J. B. (2014). Pengaruh Kompetensi, Komitmen Organisasi Dan Keterlibatan Kerja Terhadap Kinerja Karyawan Pada Pt. Pln (Persero) Wilayah Suluttenggo . Fakultas Ekonomi dan Bisnis, Jurusan Manajemen Universitas Sam Ratulangi. Jurnal EMBA 331 Vol.2 No.4 Desember 2014, Hal. 331-342 ISSN 2303-1174 